\title{
A snap on quality management in Zimbabwe: a perspectives review
}

\author{
Vitalis Basera $^{1 *}$, Judy Mwenje ${ }^{2}$, Samson Ruturi ${ }^{3}$ \\ Graduate School of Business, Bindura University of Science Education, Zimbabwe ${ }^{1 * 2,3}$ \\ vitalisbasera@yahoo.com
}

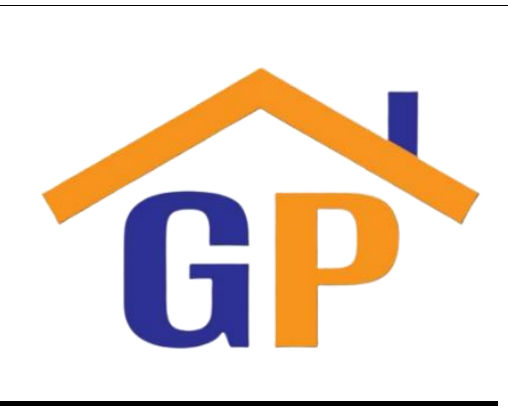

\section{Article History}

Received on 22 October 2020

$1^{\text {st }}$ Revision on 17 November 2020

$2^{\text {nd }}$ Revision on 24 November 2020

Accepted on 25 November 2020

\begin{abstract}
Purpose: The main objective of this article was to provide evidence concerning the level of Quality Management (QM) in Zimbabwe. Submitted evidence regarding $\mathrm{QM}$ in Zimbabwe will help organizations that want to implement QM systems. The results can guide government agents in making informed decisions towards QM systems implementation since very few organizations are officially quality certified.
\end{abstract}

Research methodology: The survey followed online search query on quality management in Zimbabwe from journal articles, proceedings and institutional repository. 51 publications were selected and excel file was used to capture data and analyse.

Results: The results expose that there was high interest in QM in 2014, 2015 and 2016. The results showed industries lack of capacity and resources, lack of skills and expertise, poor communication with stakeholders, poor raw materials, changing customer preferences, lack of top management commitment and costs of QM systems as key barriers to QM implementation.

Limitations: The study limitation was survey of few studies retrieved through Bindura University online library and open access journal articles, proceedings papers and dissertations/thesis available on institutional repository.

Keywords: Zimbabwe, Quality Management (QM), Drivers, Barriers, Benefits

How to cite: Basera, V., Mwenje, J., Ruturi, S. (2019). A snap on quality management in Zimbabwe: a perspectives review. Annals of Management and Organization Research, 1(2), 77-94.

\section{Introduction}

Quality Management (QM) nowadays is a need in the countenance of intensifying competition among firms and demanding business operations in different sectors of the economy. The global market, demand for high quality goods and services and the creation of quality culture among consumers makes it clear that "quality" has become universally well-defined term of customer perception and expectations beyond production of goods and services. If you ask ten people to define quality, you will probably get ten different definitions. There are many definitions of quality and it is very difficult to define quality of products and services because of their unique characteristics. Quality is defined antithetically, synonymous or even complementary by quality gurus, standard association and organizations. Quality is conformance to requirements or specifications (Crosby, 1979). Quality is a totality of features and characteristics of a product or service that bear on its ability to satisfy given needs (ASQ, 2019; ISO, 2019). Goetsch \& Davis, (2010) noted quality is not fixed but change with customers' expectations and views of the world after drawing together the themes of a number of definitions to create a unifying definition.

QM is a management philosophy that encompasses all features of quality that are of interest to both the organization and the consumer. Proper QM implies implementation of quality assurance which is the assembly of all planned and systematic actions necessary to provide adequate confidence that a product, 
process, or service will satisfy given quality requirements (ISO, 2019). Quality assessment and control warrants prevention of mistakes in production of goods and services. When implemented properly QM systems such as Six Sigma, Lean, Total Quality Management (TQM) and others can save the organizations' resources. The organisation resources can be saved through reducing operating expenses, reducing defects and wastes, speed communication and understanding customers' expectations and being competitive in the market (Madanhire \& Mbohwa, 2014; Mambanda, et al., 2017; Mahmutay, et al., 2015). Organizations in different industries (sectors of the economy) have adopted QM practices so as to be competitive despite difficulties in and outside the organizations.

The Republic of Zimbabwe is a landlocked country in Southern Africa with a population of 14439018 people as of 2019. Zimbabwe's economy is in the doldrums with shrinking Gross Domestic Product (GDP) of $8.1 \%$ and youth unemployment rate of $8.7 \%$ (World Bank, 2020). The widespread dispersion and acceptance of QM techniques will make an organization, an industry and ultimately country's economy more competitive. QM at state level lead to cumulative economic efficiency, - higher innovation and the development of human capiatl for achieving increased productivity and competitiveness levels (Ayandele \& Akpan, 2020). At national level there is Standard Association of Zimbabwe (SAZ) a quasi-government organization responsible for QM systems accreditation, training and auditing affiliated to International Standards Organization. QM initiatives at international facilitate market access by removing technical barriers to trade. In this study aspects that impact effective application of quality management such as drivers for successful implementation of QM, barriers, benefits and QM initiatives were scrutinised from published quality management literature in Zimbabwe from 2010 to 2019. Specific quality management models/systems are highlighted. This is essential for the development of QM in Zimbabwe.

From the reviewed literature it is evident that there is no literature nexus in the field of QM in Zimbabwe. Therefore, there is need for a thorough literature synthesis to provide information on drivers of QM initiatives, barriers to QM, types of QM systems and benefits of QM in order to advance QM in Zimbabwe. This literature nexus propositions evidence from the area of QM in Zimbabwe to organization that want to implement QM. Published QM literature over the past ten years (2010 to 2019) is summarised, analyzed and comments presented.

\section{Literature Review}

\subsection{Barriers to $Q M$}

Hill (2008), identified five most significant barriers to TQM implementation from a section survey of ASQ members related with an effective quality transformation. The major barriers to successful implementation were; organization's reward system was not tied to achieving quality objectives, employees lack quality improvement skills, inadequate resources to successfully employ total quality management, employees resistant to change, employees not trained in problem identification and problem-solving techniques. Three key constructs to the barriers were identified as; lack of training for quality, lack of planning for quality, and lack of leadership for quality. The size of the building project, cost and budget are two new dimensions of barriers to implementation of QM specific to construction industry (Femi, 2015). In the Nigerian manufacturing industry Ayandele \& Akpan, (2015); identified lack of financial resources, lack of moral will power and lack of top management support as barriers to QM initiatves. In financial services industry some organizations encountered challenges in the implementation of QM, because of the internal barriers, which are more related to resistant to change as equated to organizations in manufacturing industry (Mahmutay, Jusufi, Zylfijaj, \& Grubi, 2015) . The barriers to QM systems implementation were found to be pointedly related to specific possible outcomes that are used to measure success or failure of QM initiatives (Hill, 2008; Dube, 2018; Goriwondo, et al., 2012, Femi, 2015). The potential outcomes of QM initiatives failure include high turnover of employees, high management turnover, the high cost to benefit ratio of QM, and quality improvement (QI) results hardly meet expectations. 


\subsection{Drivers for successful implementation of $Q M$}

The study of QM includes the question of what are drivers or enablers for successful implementation of QM systems. According to Khoo \& Tan, (2002) in Al-Ababneh, (2016) drivers for successful implementation of QM are the critical success factors or enablers of QM which are the exercises that have to be taken appropriately for an organization to realise its goals. The acquaintance of drivers for successful implementation of QM is important in order to advance QM initiatives (Nair \& Choudhary, 2017). The examination of drivers for successful implementation of QM outlines the fundamentals to the change process to enhance QM initiatives likelihood of success. According to Nair and Choudhary (2017) and Mahmutay, et al., (2015); if all drivers for successful implementation of QM like commitment by top management and all employees, focus on customer satisfaction, training and education, employee involvement and participation, co-operation and teamwork, employee empowerment, adequate planning and monitoring, reward and recognition, strong leadership, effective communication and feedback sdevice are well in place in an organizations, QM initiatives will be successful. To develop a complete QM system, drivers for successful implementation of QM should be well-thought-out in the early phases of QM planning and designing processes (Moheel, Alkatheri, \& AlSukhayri, 2019).

\subsection{Benefits of QM Implementation}

Organizations implement QM to support what customers' demand and expect (Lee, 2016; Masrurul, 2019). A continuous improvement is a first step for quality management and a second step of excellence; it is one of the main benefits of QM. QM improves internal procedures and reduces paper work (Moheel, et al.; 2019). QM adoption improves the image and reputation in the eyes of the customers and gives a mark of respect for organizations and acts as a signal to markets and customers indicating security and conformity (Basera \& Makandwa, 2020). Adoptions of QM models such as ISO 9001 by organizations have shown significant improvement in quality of their product (Ngwenya, et al., 2016; Watiki, 2014; Isabiry \& Pelser, 2017; Chivandi \& Maziri, 2017; Chikuku, et al., 2012). Watiki (2014), studied hotels in Kenya to understand factors prompting customers satisfaction and the association between service quality and customers satisfaction. His results suggest that service quality supports $74.2 \%$ of customer satisfaction. This suggests that service quality backs $74.2 \%$ of customer satisfaction while the other issues influences $25.8 \%$ of customer satisfaction. In Bangladesh tourism organizations using quality management systems were performing well with good and effective relations with customers and employees (Masrurul, 2019). Organizations surveyed for QM adoption, the results pointed out that a high proportion of organizations being certain of their reputation, products and services improved after adopting QM initiatives (Ayandele \& Akpan, 2015; Chikosha, 2016; Dowa, 2019; Femi, 2015; Kufa, 2015; Psomas, et al., 2014).

QM implementation have led to expect design, product, processes and supplier relationships according to research done at Delta, one of the biggest beverages manufacture in Zimbabwe (Madanhirea \& Mbohwa, 2016). Benefits and improvements brought by QM are also internal improvement, greater quality awareness and improved awareness of problems within the work organizations. Product development processes based on QM have improved after QM systems implementation (Biswakarma, 2017; Heizer \& Render, 2014; Ngwenya, et al., 2016) . Quality denotes an essential state for the competitiveness of firms producing goods and services at global level in the present economy defined by stiff competition. Quality consideration is the strategic contribution that cannot be neglected in order to achieve competitiveness (Dobrin, et al., 2015; Mizanbekova, et al., 2017).

\subsection{Quality Management Models/Systems}

A number of recognised QM systems have been developed for use all over the world in different industries. According to ISO (2019) quality management system is a set of harmonized activities used to lead and control an organization in terms of quality. Internationally, the QM systems are drawn upon TQM (Juran, 2016); organizations apply different quality initiatives such as ISO 9001, continuous improvement, six sigma, lean production, benchmarking, and business excellence models. TQM is an idea of management ensuing from the work of quality authorities (Biswakarma, 2017). TQM is grounded on three important principles which are; customer orientation to satisfy customer 
requirements and expectations; process orientation (input-process-output) and continuous improvement as a derived from the works of quality experts (Deming, 1986; Ishikawa, 1985). The ISO 9000 reports on several aspects of quality management and comprises some of the ISO's eminent standards (ISO, 2019). The standards presents direction and tools for organizations that want to produce products that continuously meet customer's requirements, and of enhanced quality (Nyambwa, 2017).

Lean production originated in the Toyota Corporation, it is a yard stick of Lean Thinking which many service companies have implemented as a quality management system (Mahmutay, et al., 2015; Matombo, 2014). Its main principle is determination on identifying and refining steps in an operation that the customer considers valuable, and to remove unnecessary or wasteful steps in a process (Lee, J. Larry, \& Manoj, 2012). Six Sigma is a QM system applicable in both service and manufacturing organization than Lean (Kwaka \& Anbari, 2006). Six Sigma as a QMS has five steps which are DMAIC (define, measure, analyze, improve and control) (Heizer \& Render, 2014). Holt \& Eccles, (2015) defined benchmarking as the continuous measurement and examination of business performance and practices against the organizations which are measured as best competitors. Through benchmarking, organizations compare themselves with the finest and constantly evaluate their practices, processes and methods to assure the strength of their competitive position in relation to their competitors. Benchmarking stimulates organizations to learn and change in order to reach higher customer value (Gwimbi \& Nhamo, 2016).

Continuous Quality Improvement (CQI) is a philosophy that emphases on improving processes, practices and methods to enable companies offer customers what they primarily want at first time, every time (Chikosha, 2016). According to ASQ (2019), CQI is a continuing effort to improve products, services or processes. The efforts are aimed at incremental or breakthrough improvements product quality over time. Corporate culture creation is not core in CQI but at core is the process of quality improvement. Business Excellence (BE) models are used as QMS tools in many countries to assist organizations to improve on their performance (Ioannis \& Dimitrios, 2017; Kanji, 2012). TQM is the basis of $\mathrm{BE}$ because the fundamental ideas are the same; participation of top management, stakeholder involvement and holistic approach (Maganga, 2018; Kanji, 2012). The most distinguished BE models applied world over are Deming Prize, European Foundation for Quality Management (EFQM) model and Malcolm Baldrige National Quality Award (MBNQA).

Statistical processes control (SPC) is the use of statistical means to manage a process to confirm that it functions at its optimum potential to produce a product meeting requirements (Madanhirea \& Mbohwa, 2016). When using SPC a process is predictable producing confirming products and minimising waste as much as possible. Control charts, graphs, scatter diagrams, cause and effect diagram, pareto chart, histogram, and check sheets are seven tools in SPC (Heizer \& Render, 2014). Applicability of SPC is easy in manufacturing industry where the product quality dimensions are easy to measure than in the service sector where the service quality dimensions are not easy to measure. There are also industry specific QM systems for instance in Food industry there is Assured Safe Catering (ASC) and Hazard Analysis Critical Control Point (HACCP).

\section{Research questions}

This study objectives to offer answers to the subsequent six research questions:

1. What are the industries that have been investigated of QM in Zimbabwe?

2. What are the methods that are used in QM studies?

3. What are the barriers to QM systems?

4. What are the drivers to successful implementation of QM systems?

5. What are the QM systems or models that have been implemented in Zimbabwe?

6. What are the benefits of implementing QM systems?

\section{Research methodology}

Selected articles from online publications (journals and conference proceedings papers, thesis/dissertations) that have been published from 2010 to 2019 in the subject of Quality Management in Zimbabwe. We used search engines and database mainly: Research Gate, Google Scholar, Science 
Direct, Taylor and Francis, science Direct, Bindura University online Library. The search query was total quality management in Zimbabwe, quality management in Zimbabwe, quality assessment in Zimbabwe, quality evaluation in Zimbabwe, total quality evaluation in Zimbabwe, total quality measurement in Zimbabwe, business excellence in Zimbabwe, business excellence models in Zimbabwe and quality management systems in Zimbabwe. After a thorough read the articles of journals, proceedings and institutional repository we concluded that the research questions were met (Ioannis \& Dimitrios, 2017). We selected 51 publications and excel file was used to record data according to type of journal, year, topic, proceedings paper, thesis/dissertation, method used in the research, industry, drivers for successful implementation of QMS, barriers to QM, benefits of QM and the type of QM systems/model.

The surveyed published papers on QM in Zimbabwe provided literature on the barriers to QM in different areas, drivers for successful adoption/implementation of QM, the quality models or systems that have been implemented in Zimbabwe and the benefits of QM implementation. This paper reviews studies that have empirically and theoretically investigated Quality Management in Zimbabwe from 2010 to 2019 and discusses the results. The paper also noted gaps and way forward for future research in the area of QM within Zimbabwe.

\section{Results and discussions}

\subsection{Number of QM studies}

51 journal articles, proceedings papers and thesis/dissertations were investigated. The bulk of the studies are in journal articles $(59 \%, \mathrm{~N}=34)$ trailed by the studies in thesis/dissertation $(33 \%, \mathrm{~N}=16)$ and the least in conference proceedings papers $(8 \%, \mathrm{~N}=4)$.

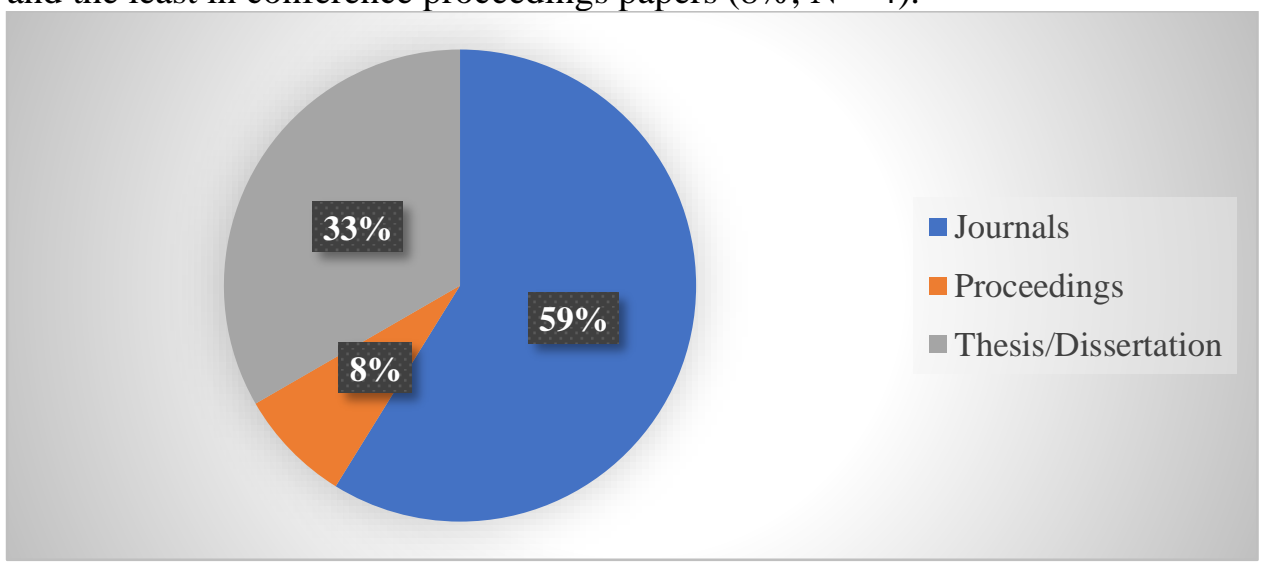

Figure 1: Number of studies from journals, proceedings and thesis/dissertations

We scrutinised journal articles, proceedings papers and thesis/dissertations published from 2010 to 2019. Majority of them have been published in $2014(\mathrm{~N}=8), 2015(\mathrm{~N}=8)$ and $2016(\mathrm{~N}=9)$. From 2010 the number have been growing and in recent years the number started going down and this confirms decreased interest in the initiatives of QM in Zimbabwe. We studied 49 empirical studies and 2 theoretical studies. 1 theoretical paper was published in 2011 and the other in 2016. 


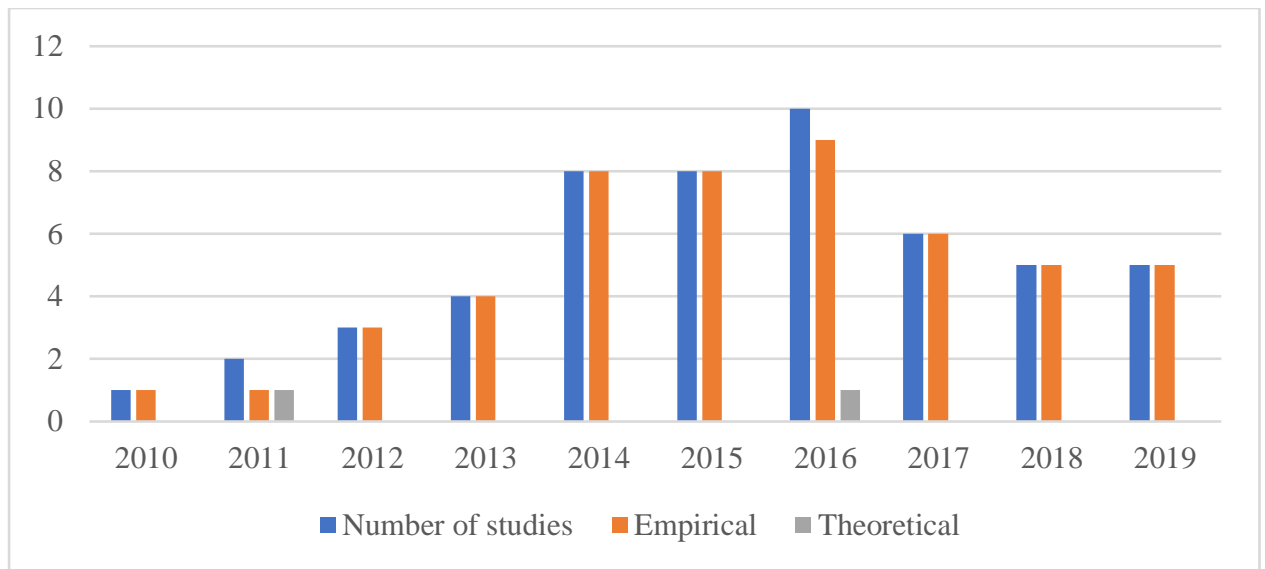

Figure 2: Number and type of studies of Quality Management per year from 2010-2019

\subsection{Industries in the research}

We examined studies from 12 industries. We characterised the studies into industries/sectors of the economy by mapping according to the topics and sub themes of interest in the studies. Alloys industry, energy industry, tobacco processing, transport, tourism and hospitality, food and beverages, manufacturing, health, mining, retail (FMCG), education and the services industry are the key industries identified from the studies.

Majority of the studies were done in Manufacturing $(\mathrm{N}=13)$, followed by Education $(\mathrm{N}=10)$, and the least of studies were done in Transport $(\mathrm{N}=1)$, Retail (FMCG) $(\mathrm{N}=1)$ and Tobacco processing $(\mathrm{N}=1)$

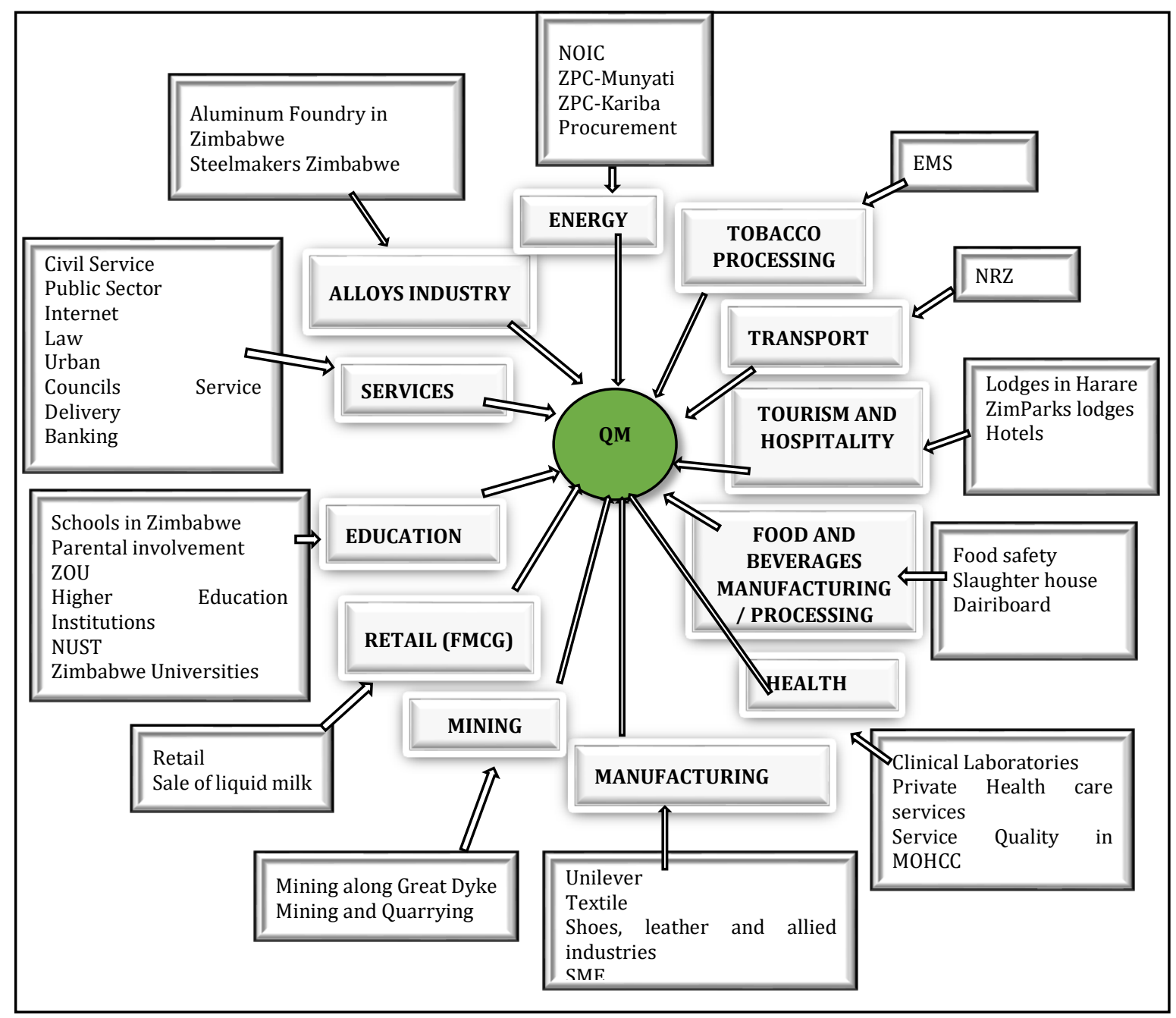




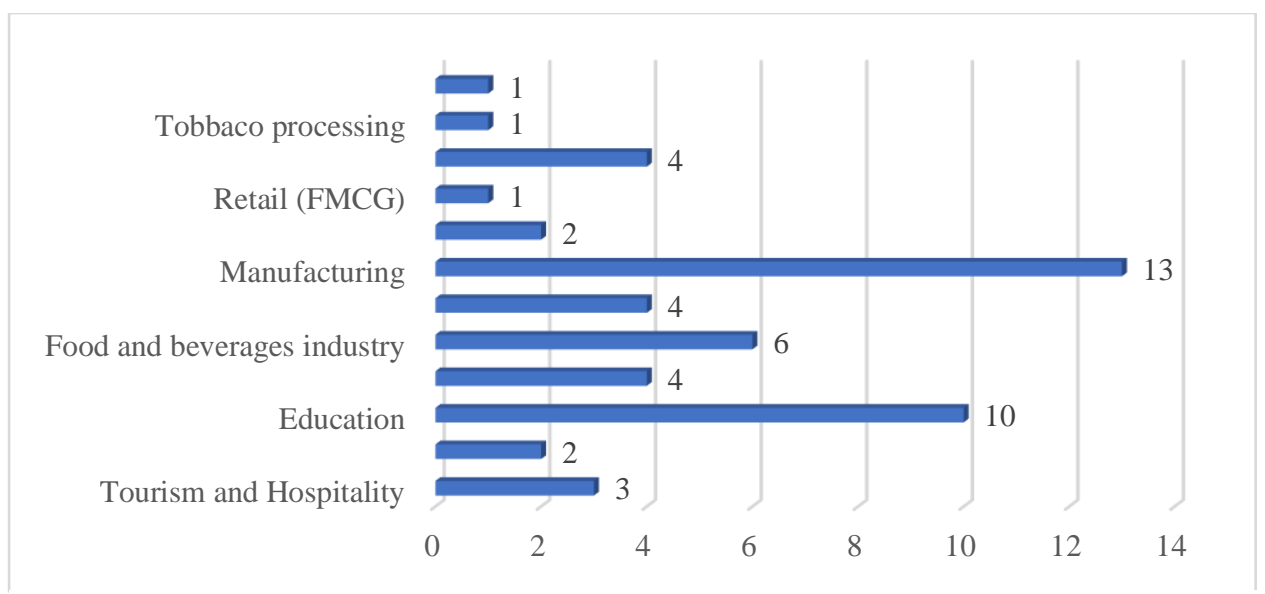

Figure 3 Industry categories in the QM studies

The fact that QM studies in Zimbabwe are done more in manufacturing, education, health, food and beverages industry, and tourism and hospitality and less on transport and retail confirm the results of Metaxas and Koulouriotis (2017). However, the results vary on public/civil service where there are less studies on QM and Metaxas and Koulouriotis (2017) results showed a high number of studies in the public sector.

\subsection{QM topics in the studies}

The very shared topics that have been discoursed in the QM studies are; Implementation of QM systems (33\%, N=36), followed by Benefits of implementing QM systems (17\%, $\mathrm{N}=19)$, Barriers to implementation of QM systems (15\%, N16), Drivers of QM implementation (14\%, N=15), QM stakeholders (13\%, $\mathrm{N}=13)$, QM Dimensions $(5 \%, \mathrm{~N}=5)$ and QM systems $(5 \%, \mathrm{~N}=5)$. The fact that $\mathrm{QM}$ studies in Zimbabwe focus more on implementation of QM systems, benefits of QM systems, drivers of QM implementation and less on QM dimensions and QM systems confirms the results of Tarí \& Dick (2016) and Papanthymou \& Darra (2017).

\subsection{Barriers to quality management implementation}

The subsequent table presents the barriers that players in different industries encounter during implementation of QM systems.

Table 1: Number of QM studies per industry

\begin{tabular}{|c|c|c|}
\hline Author & Industry & Barriers \\
\hline$\frac{{ }^{1} \text { Maphosa, }}{\frac{(2015),}{{ }^{2} \text { Chikosha, }}}$ & $\begin{array}{l}\text { Tourism and } \\
\text { hospitality }\end{array}$ & $\begin{array}{l}{ }^{1} \text { Lack of capacity and resources to sustain quality standards, lack of skills } \\
\text { and expertise, lack of quality management systems, failure to } \\
\text { communicate and relate with stakeholders in Tourism and Hospitality } \\
\text { industry } \\
{ }^{2} \text { Outdated interior designs, furniture and premises which do not suit the } \\
\text { modern-day hospitality customers and guests. }\end{array}$ \\
\hline $\begin{array}{l}{ }^{1} \text { Suruto, } \\
(2015) \\
\end{array}$ & Alloys industry & ${ }^{1}$ Lack of customer loyalty \\
\hline $\begin{array}{l}{ }^{1} \text { Madhekeni, } \\
\frac{(2012),}{2 \text { Zvavahera, }} \\
\underline{2014}\end{array}$ & Civil Service & $\begin{array}{l}{ }^{1} \text { Administration politics, patron-clientelism forces, lush administrative } \\
\text { and technical incapability. } \\
{ }^{2} \text { Shortage of finance and non-submission of employees' } \\
\text { evaluation/appraisals to the Civil Service Commission, bonus payment } \\
\text { not based on performance ratings }\end{array}$ \\
\hline $\begin{array}{l}{ }^{1} \text { Ngwenya\& } \\
\text { Pretorius, } \\
\frac{(2014)}{{ }^{2} \text { Mukwambo, }} \\
\underline{(2016)}\end{array}$ & Education & $\begin{array}{l}{ }^{1} \text { Exclusion of parents. } \\
{ }^{2} \text { Top down approach, quality as a political tool. } \\
{ }^{3} \text { Not easy to understand, time taxing, laborious. } \\
{ }^{4} \text { Policies, work overload, mobility of teachers, lack of resources. } \\
{ }^{5} \text { Resistance to change, bureaucratic Organizational structure. }{ }^{6-7} \text { Lack of } \\
\text { knowhow of the system, lack of awareness }\end{array}$ \\
\hline
\end{tabular}




\begin{tabular}{|c|c|c|}
\hline $\begin{array}{l}{ }^{4} \text { Mapolisa \& } \\
\text { Mubika, } \\
\frac{(2018)}{{ }^{5} \text { Chingara }} \\
\left(2019,{ }^{7} \text { Dube }\right. \\
\text { \& Scott, } \\
\text { (2014) }\end{array}$ & & \\
\hline Njobo, (2016) & Energy & Bureaucratic interventions and obsolete machinery \\
\hline $\begin{array}{l}{ }^{1} \text { Mambanda, et } \\
\frac{\text { al., }(2017)}{{ }^{2} \text { Macheka, et }} \\
\text { al., (2013) }\end{array}$ & $\begin{array}{c}\text { Food and } \\
\text { beverages } \\
\text { manufacturing }\end{array}$ & $\begin{array}{l}{ }^{1} \text { Inconsistent raw material quality, changes in customer preferences, } \\
\text { packaging, short product shelf life and food spoilage. }{ }^{2} \text { Inadequate } \\
\text { financial resources, organization size, poor infrastructure and facilities, } \\
\text { and uncommitted top management }\end{array}$ \\
\hline $\begin{array}{l}1 \text { Gore, et al., } \\
\frac{(2016),}{{ }^{2} \text { Masanga, et }} \\
\text { al., (2017) }\end{array}$ & Health & $\begin{array}{l}{ }^{1} \text { Lack of support from top management, resistance to change, poor } \\
\text { communication, lack of employee participation. } \\
{ }^{2} \text { Costs, Health care industry is too fragmented }\end{array}$ \\
\hline $\begin{array}{l}{ }^{1} \text { Marambanyik } \\
\underline{\text { a \& Mutekwa, }} \\
\frac{(2010),}{{ }^{2} \text { Goriwondo, }} \\
\underline{\text { et al., (2012) }} \\
\frac{{ }^{3} \text { Gombe, }}{\underline{(2014)}} \\
\frac{{ }^{4} \underline{\text { Matombo, }}}{(2014)} \\
\frac{\underline{\text { Ngwenya, et }}}{\underline{\text { al.., (2016) }}} \\
\frac{{ }^{6} \text { Nyambwa, }}{\underline{(2017)}} \\
\underline{{ }^{7} \underline{\text { Kudoma }},} \\
\underline{2015}\end{array}$ & Manufacturing & $\begin{array}{l}{ }^{1} \text { Employees lack skills. } \\
{ }^{2} \text { Lack of top management support, lack of employee innovation, poor } \\
\text { internal audits, deterrent maintenance schedule and lack of data analysis. } \\
{ }^{3} \text { Lack of employee participation, poor raw materials, unskilled personnel, } \\
\text { electricity outage, shortages of water, outdated machinery, low } \\
\text { wages/salaries } \\
{ }^{4} \text { Lack of leadership commitment, resistance to change culture. } \\
{ }^{5} \text { Economic meltdown, employee resistance to change, inadequate } \\
\text { financial resources, stiff competition from imported Cheap products, high } \\
\text { costs of manufacturing, low inventory turnover, and declining sales } \\
\text { revenues. } \\
{ }^{6} \text { Stiff market competition, lack of investors, lack of motivation of } \\
\text { employees in relation to quality behavior, lack of top management } \\
\text { commitment to quality management and inadequate technology and } \\
\text { resources for producing quality products. } \\
{ }^{7} \text { Low level of education, lack of customer and supplier focus, } \\
\text { unempowered employees }\end{array}$ \\
\hline $\begin{array}{l}{ }^{1} \text { Gwimbi \& } \\
\text { Nhamo, } 2016 \\
\end{array}$ & Mining & $\begin{array}{l}{ }^{1} \text { Vagueness in the regulations regarding baseline data collection and } \\
\text { analysis and conceptualisation of mitigation }\end{array}$ \\
\hline $\begin{array}{l}{ }^{1} \text { Denhere, et } \\
\text { al., } 2011\end{array}$ & $\begin{array}{l}\text { Service - City } \\
\text { Local Authority }\end{array}$ & $\begin{array}{l}{ }^{1} \text { Inadequate and broken service delivery, poor management strategies, } \\
\text { human resource problems, bad governance structures (organogram) and } \\
\text { political meddling }\end{array}$ \\
\hline
\end{tabular}

Over laying barriers to adoption of QM systems in nearly all the noted industries are lack of capacity and resources, lack of skills and expertise, poor communication with stakeholders, poor raw materials, changing customer preferences, lack of top management commitment, costs of QM system, these barriers were also noted by Femi (2015) and Yarahmadi \& Magd (2016). Table 1 also reveals the following barriers perculiar to civil service and hospitality and tourism industry.

\section{Cilvil service:}

- Administration politics

- Patron clientelism forces

- Rampant administration

- Technical inefficincy

- Non sumbmission of Results Based Management (RBM) appraisal

Hospitality and tourism industry

- Outdated interior designs, furniture and premises

\subsection{Drivers for QM systems implementation}

Table 2 presents the drivers of QM systems implementation in various industries. Customer focus, employee involvement, management support, financial resources, teamwork, supplier focus, employee skills and knowledge and customer focus were noted as key drivers for successful implementation of 
QM system across the industries of tourism and hospitality, alloys industry, civil service, energy, food and beverages manufacturing, health, banking, manufacturing, mining, and service which is line with other studies of Biswakarma (2017); Ayandele \& Akpan (2015); Caccamo, et al., (2018); Yarahmadi \& Magd (2016); Shirbavikar (2018); and Mahmutay, et al., (2015). QMS in most industries is driven by the internal and external factors which training and auditing of workers. Unique drivers were observed in food and beverages manufacturing, where it is mandatory to take up a QM system as a standard operating procedure for regulatory compliance and microbial assessment scheme. In internet provision implementation of QM system is driven by the need to provide reliable service at best prices responding to price sensitiveness of customers.

Table 2: Drivers of QM systems implementation

\begin{tabular}{|c|c|c|}
\hline Author & Industry & Drivers \\
\hline $\begin{array}{l}{ }^{1} \text { Madanhire, } \\
\frac{\text { et al., (2013); }}{\frac{{ }^{2} \text { Suruto }}{(2015)}}\end{array}$ & $\begin{array}{l}\text { Alloys } \\
\text { industry }\end{array}$ & $\begin{array}{l}{ }^{1} \text { Proximity to customers and suppliers, the presence of a extremely } \\
\text { competitive market, a wide product range, size of company, the presence of } \\
\text { high manufacturing technology and a short degree of vertical organisation } \\
{ }^{2} \text { Management and employee participation and commitment, customer focus }\end{array}$ \\
\hline$\frac{{ }^{1} \text { Mavaza, et }}{\text { al., (2017) }}$ & Banking & $\begin{array}{l}{ }^{1} \text { Top management support and their full commitment, better understanding } \\
\text { of TQM among staff, employee empowerment }\end{array}$ \\
\hline $\begin{array}{l}{ }^{1} \text { Chingara } \\
(2019), \\
\text { Nyuke \& } \\
\frac{\text { Gasva }(2015)}{{ }^{2} \text { Ngwenya \& }} \\
\underline{\text { Pretorius }} \\
\underline{(2014)}\end{array}$ & Education & $\begin{array}{l}{ }^{1} \text { Understanding leadership, use of agency and structure. Customer focus, } \\
\text { staff involvement, objective information and data analysis, mutual } \\
\text { relationship with stakeholders. } \\
{ }^{2} \text { Continuous improvement }\end{array}$ \\
\hline $\begin{array}{l}{ }^{1} \text { Masanganise } \\
\frac{\text { et al. (2013), }}{{ }^{2} \text { Mambanda, }} \\
\text { et al. (2017) }\end{array}$ & $\begin{array}{l}\text { Food and } \\
\text { beverages } \\
\text { manufacturing }\end{array}$ & $\begin{array}{l}{ }^{1} \text { Assessment scheme of microbial, compliance to regulations, standard } \\
\text { operating procedures (SOP), external and internal auditing, workers } \\
\text { training. } \\
{ }^{2} \text { Customer focus, management and leadership commitment, strategic } \\
\text { quality planning, supplier management, training employees, continuous } \\
\text { improvement (CI), statistical quality control }\end{array}$ \\
\hline $\begin{array}{l}{ }^{1} \text { Gore, et al. } \\
\frac{(2016)}{{ }^{2} \text { Marufu, et }} \\
\underline{\text { al. }(2014)}\end{array}$ & Health & $\begin{array}{l}{ }^{1} \text { Management commitment, teamwork and employee participation, process } \\
\text { management, customer focus, resources management, behavior and culture } \\
\text { of organization, continuous improvement }(\mathrm{CI}) \text {, and training of employees. } \\
{ }^{2} \text { Customer complaints increase as a result of delayed turnaround times, } \\
\text { service delivery unreliable and laboratory results errors. }\end{array}$ \\
\hline${ }^{1}$ Virima, et al. & $\begin{array}{l}\text { Internet } \\
\text { service }\end{array}$ & $\begin{array}{l}{ }^{1} \text { Reliability, responsiveness and prices-sensitive offerings are key to } \\
\text { satisfying customers }\end{array}$ \\
\hline 2014) & Legal services & $\begin{array}{l}{ }^{1} \text { Continuous legal training of lawyers, education and training of Senior and } \\
\text { Managing Partners and all lawyers on TQM }\end{array}$ \\
\hline $\begin{array}{l}{ }^{1} \mathrm{Ngwenya}, \text { et } \\
\text { al. (2016) }\end{array}$ & $\begin{array}{l}\text { Manufacturin } \\
\mathrm{g}\end{array}$ & ${ }^{1}$ Management support, clear communication, shop floor employees support \\
\hline${ }^{1}$ Goriwondo & $\begin{array}{c}\text { Retail } \\
\text { (FMCG) }\end{array}$ & $\begin{array}{l}{ }^{1} \text { Ubuntu, Leadership Purpose - Vision and Mission, People Involvement, } \\
\text { Culture, Values }\end{array}$ \\
\hline $\begin{array}{l}{ }^{1} \text { Chipoyera } \\
(2013) \\
\end{array}$ & $\begin{array}{c}\text { Tobacco } \\
\text { processing }\end{array}$ & ${ }^{1}$ Top management commitment and clear environmental policy \\
\hline$\underline{\underline{(2018)}}$ & Transport & $\begin{array}{l}{ }^{1} \text { Knowledge sharing, a commitment to be excellent by everyone and focus } \\
\text { on leadership, cross-functional teams, accurate diagnosis of forces of } \\
\text { change and implementation of apposite change principles, adoption } \\
\text { business process reengineering }\end{array}$ \\
\hline
\end{tabular}

\subsection{Benefits of QM systems implementation}

Table 3 summarises and shows the benefits of implementing of QM systems. The benefits of adopting QM systems are relatively similar in all the industries. Many benefits have been noted in the manufacturing industry which are;

- Reduction of production waste, costs, process time, product defects, returns and reworks. 
- Improved sales, market share and partner relationship. Improvements in total quality, job scope/descriptions, facilitation of meetings, department benchmarking.

- Increase of profits, revenue, sales, products quality.

- Improving environmental performance, reduction in waste, water consumption, energy consumption.

- Increases - capacity utilization and competitiveness, employee pride and motivation, product development, equipment effectiveness, organizational communication, provision of appropriate tools to employees, revenue per employee and employee retention.

- Improved operational performance. Improving organizational performance, product quality, customer satisfaction, efficiency

The results confirm to the studies of Biswakarma (2017); Mizanbekova, et al., (2017); Irechukwu (2010); Metaxas \& Koulouriotis (2017); Papanthymou \& Darra,(2017).

Table 3: Benefits of QM systems implementation

\begin{tabular}{|c|c|c|}
\hline Author & Industry & Benefits \\
\hline $\begin{array}{l}{ }^{1} \text { Madanhire, et al., } \\
\frac{(2013),}{2}{ }^{2} \text { Suruto }\end{array}$ & $\begin{array}{l}\text { Alloys } \\
\text { industry }\end{array}$ & $\begin{array}{l}{ }^{1} \text { Reduce throughput times and production costs, non-capital intensive. } \\
{ }^{2} \text { Improved Organizational performance, increases workforce's morale } \\
\text { and reduce costs such on reworks and returns }\end{array}$ \\
\hline${ }^{1}$ Mavaza, et al. & Banking & More satisfied and loyal customers \\
\hline $\begin{array}{l}{ }^{1} \text { Chingara, (2019); } \\
\frac{\text { Mapolisa \& }}{\text { Mubika }(2018)} \\
\frac{{ }^{2} \text { Tapera \& Kuipa }}{(2016)} \\
\frac{{ }^{3} \text { Mukwambo }}{2016) ;} ;{ }^{4} \text { Nyenya } \\
\frac{\text { \& Gabi }(2016)}{2016)}\end{array}$ & Education & $\begin{array}{l}{ }^{1} \text { Improve academic quality in their schools. Effective research } \\
\text { supervision. } \\
{ }^{2} \text { Good student grades, achievement of learning outcomes, } \\
\text { demonstration of the requisite knowledge, skills and expertise upon } \\
\text { graduation and joining industry. } \\
\text { 3Improved teaching and learning, research and managerial practice, } \\
\text { institution receiving. }{ }^{4} \text { Customer satisfaction improved, University } \\
\text { ranking improved, Academics research output has increased }\end{array}$ \\
\hline $\begin{array}{l}{ }^{1} \text { Dube (2018); } \\
{ }^{2} \text { Njobo (2016); } \\
{ }^{3} \text { Zhanda (2016); } \\
{ }^{4} \text { Munyimi (2019) }\end{array}$ & Energy & $\begin{array}{l}{ }^{1} \text { Enhance performance of the company in terms of profitability, } \\
\text { market share and company image, result in good employer-employee } \\
\text { relations through employee engagement, business growth, improved } \\
\text { process documentation, consistency of processes, increased } \\
\text { productivity, cost reduction, increased commitment to quality and } \\
\text { improved service delivery. } \\
\text { 2Improve employee performance and customer satisfaction. } \\
{ }^{3} \text { Improved service delivery, customer satisfaction, continuous } \\
\text { improvement. } \\
{ }^{4} \text { Reduce procurement costs and improve service delivery. }\end{array}$ \\
\hline $\begin{array}{l}{ }^{1} \text { Mambanda, et al. } \\
\underline{(2017)} ;\end{array}$ & $\begin{array}{c}\text { Food and } \\
\text { beverages } \\
\text { manufacturing }\end{array}$ & $\begin{array}{l}{ }^{1} \text { Improved - operational and market performance, product quality and } \\
\text { safety, employee skills, company image, product sales, market share, } \\
\text { and entrée to new markets. }\end{array}$ \\
\hline $\begin{array}{l}{ }^{1} \text { Sembajwe, et al., } \\
\underline{(2018)}\end{array}$ & Health & $\begin{array}{l}{ }^{1} \text { Improved turnaround time for results, data quality improved, } \\
\text { improved laboratory information management workflow and results } \\
\text { reporting, high user satisfaction }\end{array}$ \\
\hline${ }^{1}$ Duve (2011) & Education & $\begin{array}{l}{ }^{1} \mathrm{~A} \text { bias for action, near to the customer, autonomy and } \\
\text { entrepreneurship, productivity through people, stick to the knitting, } \\
\text { hands on value driven, simultaneous, loose tight principle,simple } \\
\text { form lean staff, leadership }\end{array}$ \\
\hline $\begin{array}{l}{ }^{1} \text { Madanhire \& } \\
\frac{\text { Mbohwa }(2014) ;}{\frac{\text { Ngwenya, et al., }}{(2016) ;} ; \text { Dowa }} \\
\frac{(2019) ;}{{ }^{3} \text { Marambanyika \& }}\end{array}$ & Manufacturing & $\begin{array}{l}{ }^{1} \text { Reduction of production waste, costs, process time, product defects, } \\
\text { returns and reworks. }{ }^{2} \text { Improved sales, market share and partner } \\
\text { relationship. Improvements in total quality, job scope/descriptions, } \\
\text { facilitation of meetings, department benchmarking. } \\
{ }^{3} \text { Increase of profits, revenue, sales, products quality. }\end{array}$ \\
\hline
\end{tabular}




\begin{tabular}{|c|c|c|}
\hline $\begin{array}{l}\frac{\text { Mutekwa (2010); }}{{ }^{4} \text { Chikuku, et al.. }} \\
\frac{(2012) ;}{{ }^{5} \text { Maware }} \\
\text { \& Adetunji } \\
\frac{(2019) ;}{{ }^{6} \text { Matombo (2014); }}\end{array}$ & & $\begin{array}{l}{ }^{4} \text { Improving environmental performance, reduction in waste, water } \\
\text { consumption, energy consumption. } \\
{ }^{5} \text { Increases - competitiveness in capacity utilization, product } \\
\text { development, overall equipment effectiveness, employee Motivation } \\
\text { and pride, provision of suitable tools to employees, organizational } \\
\text { communication, employee retention, revenue per employee. } \\
{ }^{6} \text { Improved operational performance. Improving organizational } \\
\text { performance, product quality, customer satisfaction, efficiency }\end{array}$ \\
\hline${ }^{1}$ Mabika 2018 & Mining & $\begin{array}{l}{ }^{2} \text { Designed the workplace, trained and developed employees, and } \\
\text { empowered and equipped employees }\end{array}$ \\
\hline $\begin{array}{l}{ }^{1} \text { Goriwondo } \\
\frac{(2015) ;}{2}{ }^{2} \text { Chivandi } \\
\text { \& Maziriri (2017) }\end{array}$ & $\begin{array}{l}\text { Retail } \\
\text { (FMCG) }\end{array}$ & $\begin{array}{l}{ }^{1} \text { Knowledge and Skill, Sub-cultures Motivation, Buy-in, Equipment } \\
\text { and Support, infrastructure, Innovation, Effective, Value Addition, } \\
\text { Technology, Choice of, WCM, principle(s), Effective } \\
\text { Communication, Cultural Adaptation, Training, Feedback. } \\
{ }^{2} \text { Meeting customer's expectations, improving work operations } \\
\text { efficiency and helpful as a marketing tool }\end{array}$ \\
\hline${ }^{1}$ Chipoyera, 2013 & $\begin{array}{l}\text { Tobacco } \\
\text { processing }\end{array}$ & ${ }^{1}$ Reduction of waste \\
\hline
\end{tabular}

\subsection{QM systems that have been implemented}

Table 4 summarises and presents the QM systems that have been implemented in different industries. Quality management systems such as TQM, SPC, ISO 9001:2008, ISO 14001, ISO 22001, Lean and Six Sigma (Metaxas \& Koulouriotis, 2017; Papanthymou \& Darra, 2017) have been implemented in different industries. This study shows other QM systems/models that have been implemented in from 2010 to 2019 in different industries; Results Based Management in the civil service, Stepwise Laboratory Improvement Process towards Accreditation (SLIPTA), STOF model (Service domain, Technology domain, Organization domain and Finance domain), LIMS (Laboratory Management Information Systems) in the health sector.

According to the results in Table 7; TQM, ISO 9001 and benchmark are the most used QM systems they are applicable in all industries and the results are in line with Metaxas \& Koulouriotis (2017). The results also showed industry specific QM systems like HACCP for food and beverages manufacturing industry and Sakai Education Managemenet Sytems for higher education management. The study examined published research from 2010 t0 2019 to determine the barriers to implementation QM, the dirivers of QM implementation, the benefits of QM implementation and the QM systems predominantly in use across different industries in Zimbabwe. It is of significance to note that $59 \%$ of the studies are from journal articles and many studies were done in manufacturing industry making headway to adopt QM systems and realise benefit of such.

Most of the studies were done in 2013 to 216 which might be a signal of QM systems implementation directly related to business environmenment, from 2016 to 2019 the studies declined as the country's economy was also going in the doldrums (World Bank, 2020). The studies showed that the organizations in different industries were operating competitively in turbulent business environment (Madanhire \& Mbohwa, 2014; Macheka, et al., 2013). There are QM systems from manufacturing industry such as TQM, Lean, Six Sigma and others Health sector such as SLIPTA and food and beverages such as HACCP which are not applicable across industries (Papanthymou \& Darra, 2017).

The most common QM systems that have been implemented in Zimbabwe industries are TQM, ISO 9001, ISO 14001 and Benchmarking. Main reasons for adoption of QM system are the benefits that an organization gain such as reduction of production waste, costs, process time, product defects, returns and reworks, increase of profits, revenue, sales, products quality and increases competitiveness. It was distinguished that customer focus, employee involvement, management support, financial resources, teamwork, supplier focus, employee skills and knowledge and customer focus are key drivers for successful implementation of QM system across the industries. Lack of capacity and resources, lack of 
skills and expertise, poor communication with stakeholders, poor raw materials, changing customer preferences, lack of top management commitment, costs of QM system were noted as key barriers to implementation of QM systems.

Table 4: QM systems implemented

\begin{tabular}{|c|c|c|}
\hline Author & Industry & QM Model \\
\hline $\begin{array}{l}{ }^{1} \text { Chikosha (2016), } \\
{ }^{2} \text { Maphosa (2015) }\end{array}$ & $\begin{array}{c}\text { Tourism and } \\
\text { hospitality industry }\end{array}$ & $\begin{array}{l}{ }^{1} \text { TQM, Continuous improvement. } \\
{ }^{2} \text { ZTA Quality standards, Quality circles, Six Sigma }\end{array}$ \\
\hline $\begin{array}{l}{ }^{1} \text { Madanhire, et al. } \\
\frac{(2013) ;}{{ }^{2} \text { Suruto }(2015)}\end{array}$ & Alloys industry & $\begin{array}{l}{ }^{1} \text { JIT. } \\
{ }^{2} \text { ISO } 9001: 2008\end{array}$ \\
\hline${ }^{1} \underline{\text { Mavaza, et al. } 2017}$ & Banking & ${ }^{1} \mathrm{TQM}$ \\
\hline $\begin{array}{l}{ }^{1} \text { Zvavahera (2014); } \\
{ }^{2} \text { Madhekeni (2012) }\end{array}$ & Civil Service & $\begin{array}{l}{ }^{1} \text { RBM (Results Based Management Model). } \\
{ }^{2} \text { RBM (Results Based Management Model), }\end{array}$ \\
\hline $\begin{array}{l}{ }^{1} \text { Chingara (2019); } \\
{ }^{2} \text { Ngwenya \& Pretorius } \\
\text { (2014) }\end{array}$ & Education & $\begin{array}{l}{ }^{1} \mathrm{TQM} . \\
{ }^{2} \mathrm{TQM}, \text { Benchmark }\end{array}$ \\
\hline $\begin{array}{l}{ }^{1} \text { Dube (2018); } \\
{ }^{2} \text { Munyimi (2019) }\end{array}$ & Energy & $\begin{array}{l}{ }^{1} \text { ISO } 9001: 2008 . \\
{ }^{2} \text { Value engineering, variety reduction, standardisation and } \\
\text { specifications. }\end{array}$ \\
\hline $\begin{array}{l}{ }^{1} \text { Chivandi \& Maziriri } \\
\text { (2017); }{ }^{2} \text { Mambanda, et } \\
\text { al. (2017); }{ }^{3} \text { Masengu \& } \\
\text { Mangwenda (2017); } \\
{ }^{4} \text { Goriwondo (2015) }\end{array}$ & Retail (FMCG) & $\begin{array}{l}{ }^{1} \text { ISO } 2200 . \\
{ }^{2} \mathrm{TQM} \text {. ISO } 9001 . \\
{ }^{3} \mathrm{HACCP} \text {. } \\
{ }^{4} \text { World Class Manufacturing (WCM) principle(s), } \\
\text { WILGOR Framework of Manufacturing Excellence }\end{array}$ \\
\hline${ }^{1} \underline{\text { Masanganise, et al., }}$ & $\begin{array}{l}\text { Food and beverages } \\
\text { industry }\end{array}$ & ${ }^{1} \mathrm{HACCP}$, ISO 9001 \\
\hline $\begin{array}{l}{ }^{1} \text { Gore, et al. (2016). } \\
{ }^{2} \text { Marufu, et al. (2014); } \\
{ }^{3} \text { Masanga, et al. (2017); } \\
{ }^{4} \text { Sembajwe, et al. (2018) }\end{array}$ & Health & $\begin{array}{l}{ }^{1} \text { TQM. SLIPTA (Stepwise Laboratory Improvement } \\
\text { Process towards Accreditation). } \\
{ }^{2} \text { STOF model (Service domain, Technology domain, } \\
\text { Organization domain and Finance domain). } \\
{ }^{3} \text { TQM } \\
{ }^{4} \text { Laboratory Information Management System (LIMS). }\end{array}$ \\
\hline${ }^{1}$ Dube \& Scott (2014) & Higher Education & ${ }^{1}$ Sakai Learning Management System \\
\hline${ }^{1}$ Chikwengo (2014) & Legal services & ${ }^{1} \mathrm{TQM}$ \\
\hline $\begin{array}{l}\frac{{ }^{1} \text { Madanhire \& Mbohwa }}{(2014) ;} \\
\frac{{ }^{2} \text { Ngwenya, et al., }(2016) ;}{3 \text { Goriwondo, et al., }} \\
\frac{(2012) ;{ }^{4} \text { Dowa (2019); }}{{ }^{5} \text { Marambanyika \& }} \\
\underline{\text { Mutekwa (2010); }} \\
{ }^{6} \text { Chikuku, et al. },(2012) ; \\
\underline{{ }^{7} \text { Maware \& Adetunji }} \\
\underline{(2019) ;{ }^{8} \text { Matombo }} \\
\frac{(2014) ;}{{ }^{9} \text { Nyambwa (2017); }} \\
{ }^{10} \underline{\text { Kudoma }(2015) ;}\end{array}$ & Manufacturing; & $\begin{array}{l}{ }^{1} \text { TQM, SPC. } \\
{ }^{2} \text { TQM. ISO 9001:2008. } \\
{ }^{3} \text { TQM. ISO 14001 EMS. } \\
\text { 4-6 ISO 9001:2008. } \\
{ }^{7} \text { Lean manufacturing. } \\
{ }^{8} \text { Lean Six Sigma. } \\
{ }^{9} \text { ISO 9001. } \\
\text { 10 TQM. }\end{array}$ \\
\hline $\begin{array}{l}{ }^{1} \text { Gwimbi \& Nhamo } \\
(2016) .{ }^{2} \text { Mabika (2018). }\end{array}$ & Mining & $\begin{array}{l}{ }^{1} \text { Benchmarking. } \\
{ }^{2} \text { Deming's plan-do-study-act cycle theory }\end{array}$ \\
\hline${ }^{1}$ Chipoyera 2013 & Tobacco processing & ${ }^{2}$ EMS (Environmental Management Systems) \\
\hline${ }^{1}$ Maganga (2018) & Transport & ${ }^{1}$ BEM (Business Excellence Model) \\
\hline
\end{tabular}

The QM stakeholders, quality measurement and quality dimensions have not been discussed and the studies methods are more empirical (98\%) than theoretical. The evidence on published QM studies is not encouraging as we noticed a gradual decrease in studies in recent years and very few conferences on QM. 


\section{Conclusion}

The study is a substantial input for researchers captivated in QM, it provides evidence of QM in different industries and sub sectors in Zimbabwe. The study propositions valuable evidence to organizations that may want to adopt QM systems regarding the drivers that effect the successful implementation of QM, barriers that hinder QM implementation, the benefits of adopting QM and the probable QM systems that can be implemented. Submitted evidence regarding QM in Zimbabwe will help prepare other organizations that want to implement QM systems for sustainable competitiveness. The results can guide government agents that are responsible for quality management in making informed decisions towards QM systems implementation since very few organizations are officially quality certified.

The identified paybacks of QM can inspire organizations to consider QM implementation for their competitive continued existence in an aggressive environment. Organizations that benchmark with others and possessing elementary understanding of QM can strategy well for quality enhancement. Unique barriers of QM adoption specific to industries were revealed, drivers for successful QM implementation, benefits of QM and types QM systems. The literature nexus consolidated literature in a systematic way in the area of QM in Zimbabwe. There is abundance of themes that can be reviewed which include quality dimensions, QM stakeholders and quality measurement across different industries.

\section{Limitations and study forward}

The limitation of this study was to survey limited studies retrieved through Bindura University online library and open access journal articles, proceedings papers and dissertations/thesis available on institutional repository. There is need for more literature on QM systems from different industries finetuned to the country business environment. Drivers for successful implementation of QM are many accordingly further researches on weighting the drivers is important. Furthermore, a comparison between different industries QM drivers, barriers, benefits and QM systems would be thoughtprovoking.

\section{Acknowledgement}

Special mention to Dr Judy Mwenje and Dr Sam Ruturi, my PHD supervisors, the two contributed a lot to the shaping of this article.

\section{References}

Al-Ababneh, M. M. (2016). Employees' perspectives of service quality in hotels. Research in Hospitality Management, 6(2), 189-194.

Apex Hotels. (2018). Apex hotels. Retrieved June 10, 2018, from http://www.rkmsuk.co.uk/casestudies/apex_hotels.

ASQ. (2019). American society for quality. Retrieved April 6, 2019, from https://asq.org

Ayandele, I. A., \& Akpan, P. (2015). The practice, challenges and benefits of Total Quality Management (TQM) in manufacturing firms in Nigeria. International Journal of Economics and Business Management, 3(5), 62-74.

Basera, V., \& Makandwa, G. (2020). Customers' perceptions, expectations and expectations and experiences of service quality for hotels in Mutare, Zimbabwe. Journal of Gastronomy, Hospitality and Travel, 3(1), 51-63.

Biswakarma, G. (2017). Effectiveness of total quality management in nepal: a case study of hospitality sector of hospitality sector. International Journal of Research in Business Studies and Management, 4(5), 32-40.

Caccamo, A., Zaida, J., Taylor, D., \& Bulatovic-Schumer, R. (2018). Measuring and improving food safety culture in a five-star hotel: a case study", Worldwide Hospitality and Tourism Themes. Journal of African Business, 10(3), 345-357.

Cardiff University. (2018). Cardiff University. Retrieved May 25, 2018, from http://www.cardiff.ac.uk/lean/principles/ 
Cheng, B. L., \& Rashid, M. Z. (2013). Service quality and the mediating effect of corporate image on the relationship between customer satisfaction and customer loyalty in the Malaysian Hotel industry. Gadjah Mada International Journal of Business, 15(9).

Chikosha, F. (2016). Measuring continuous improvement culture in the hospitality industry in Zimbabwe: a case study of Zimparks Lodges. Journal of Business and Management, 18(6), 41-44.

Chikuku, T., Chinguwa, S., \& Macheka, M. (2012). Evaluation of the impact of obtaining ISO 9001:2008 Quality Management System (QMS) certification by manufacturing companies in Zimbabwe. International Journal of Engineering Science and Technology, 4(9).

Chikwengo, R. (2014). An investigation into Total Quality Management (TQM) strategies that can be enforced by the Law Society of Zimbabwe (LSZ) with a view of improving quality of service amongst its membership (2005-2012). Thesis. Harare: University of Zimbabwe, Graduate School of Management.

Chingara, R. (2019). Leadership and organizational structure as requisite for Total Quality Management to improve academic quality in schools in Zimbabwe. Thesis. Northwest University.

Chipoyera, B. (2013). Effectiveness of Environmental Management Systems (EMS): a case of tobacco processors Zimbabwe (PVT) ltd. Thesis. Bindura: Bindura University of Science Education.

Chivandi, A., \& Maziriri, E. T. (2017). An evaluation of ISO 22000 food safety standards awareness and implementation in Zimbabwean branded fast food outlets: customer, employee and management perspectives. African Journal of Hospitality, Tourism and Leisure, 6(2).

Codex. (2016). HACCP system and guidelines for its application, codex alimentarius commission food hygiene basic texts, food and agriculture organization of the United Nations, World Health Organization. Italy: Codex Alimentarius Commission.

Crosby, P. (1979). Quality is free. New York: McGraw-Hill.

Deming, W. E. (1986). Out of the crisis. Cambridge, MA: MIT Center for Advanced Engineering Study.

Denhere, W., Tafirei, F., Zivanai, O., Muchingami, L., \& Chingarande, A. (2011). The quality of service delivery in Zimababwean urban councils: A case of Bindura Municipality 2009 to 2011. European Journal of Business and Economics, 5.

Dick, M. T., \& Thondhlana, S. (2015). Perceptions of students and staff on quality assurance in the departments of mathematics, statistics and educational studies in Zimbabwe Open University Midlands Region. Asian Journal of Humanities and Social Sciences, 3(1).

Dobrin, C., Ginearta, A., Mase, M., \& Croitoru, O. (2015). Quality: a determinant factor of competitiveness - the evolution of iso certifications for management systems. Bucharest, Romania: Proceedings of the 9th International Management Conference , November 5th-6th,: Management and Innovation For Competitive Advantage.

Dowa, R. (2019). The impact of Total Quality Management (TQM) on organizational profitability. a case of Dairibord Zimbabwe ltd. Dissertation. Bindura: Bindura University.

Dube, A. (2018). Implementation on organizational performance in Zimbabwe state owned companies: a case for the national oil infrastructure company of Zimbabwe (NOIC). Thesis. Bindura: Bindura University of Science Education.

Dube, S., \& Scott, E. (2014). An empirical study on the use of the Sakai Learning Management System (LMS): case of NUST, Zimbabwe. Proceedings of the e-skills for knowledge production and innovation conference 2014, 101-107. Cape Town, South Africa: http://proceedings.e-skillsconference.org.

Duve, R. (2011). Achieving research excellence Zimbabwean universities: A review based on the eight anchor elements characterizing excellent companies. The Dyke, 5(2).

Erwin, R., Andreas, D., Holziner, P., \& Dominik, T. (2016). Lean Hospitality. Application of Lean Management methods in the hotel sector.

Femi, O. T. (2015). Barriers and benefits of Total Quality Management in the Nigerian construction industry: a review. International Journal of Engineering Works, 2(1), 7-13.

Garwe, E. C. (2012). Quality assurance in higher education in Zimbabwe. Research in Higher Education Journal. 
Geraedtsa, H. P., Montenariea, R., \& van Rijk, P. P. (2001). The benefits of total quality management. Computerized Medical Imaging and Graphics, 25, 217-220.

Goetsch, L. D., \& Davis, B. S. (2010). Quality management for organizational excellence. Introduction to Total Quality Management (6th ed.). Pearso, Prentice Hall.

Gombe, C. (2014). An evaluation of the quality control systems used in the shoes, leather and allied products industry; a case study of the Zimbabwe Bata Shoe Company, Gweru. Dissertation. Gweru: Midlands State University.

Gore, S. N., Sithole, K., \& Gondo, K. (2016). The effectiveness' of Total Quality Management in service quality of Ministry of Health and Child Care. Journal Of Humanities And Social Science, 21(9.2), 95-98.

Goriwondo, W. M. (2015). Framework towards successful implementation of world class manufacturing principle(s). A Multiple case study of the fast moving consumer goods (FMCG) in ZIMBABWE. Journal of Science \& Technology, 10, 163-175.

Goriwondo, W. M., Zimwara, D., Mhlanga, S., Mutopa, C. T., Nkomo, F., Gutu, T., \& Ngwena, P. (2012). Challenges faced by manufacturing companies in sustaining conformance to ISO9001:2008 in Zimbabwe: A Case Study of a Textiles Manufacturing Company. International Journal of Innovative Technology and Exploring Engineering, 2(1).

Gorondutse, A. H., \& Hillman, H. (2014). Mediation effect of customer satisfaction on the relationships between service quality and customer loyalty in the Nigerian foods and beverages industry. International Journal of Management Science and Engineering Management, 9, 1-8.

Gwimbi, P., \& Nhamo, G. (2016). Benchmarking the effectiveness of mitigation measures to the quality of environmental impact statements: lessons and insights from mines along the Great Dyke of Zimbabwe. Environ Dev Sustain, 18, 527-546.

Heizer, J., \& Render, B. (2014). Operations management: sustainability and Supply Chain Management (12th ed.). Australia: Pearson.

Hemmington, N., Kim, P. B., \& Wang, C. (2018). Benchmarking hotel service quality using twodimensional importance-performance benchmark vectors (IPBV). Journal of Service Theory and Practice, 28(1), 2-25.

Hill, D. A. (2008). What makes total quality management work: a study of obstacles and outcomes. Thesis. Capella University.

Holt, A., \& Eccles, T. (2015). Financial reporting for commercial service charges in the retail sector: Benchmarking practice standards for UK shopping centres. Property Management, 33(2), $152-172$.

Huseyin, A. (2012). Towards business excellence in the hospitality industry: A case for 3-, 4-, and 5star hotels in Iran. Total Quality Management, 23(5), 573-590.

Ioannis, M., \& Dimitrios, E. K. (2017). Business excellence measurement: a literature analysis (19902016). Total Quality Management \& Business.

Irechukwu, N. E. (2010). Quality improvement in a global competitive marketplace- success story from Nigeria. International Journal of Business and Management, 5(1).

Isabiry, F., \& Pelser, T. G. (2017). Effect of service quality on occupancy levels at Molopo Lodge in Mafikeng, South Africa. African Journal of Hospitality,Tourism and Leisure, 6(3).

Ishikawa, K. (1985). What is Total Quality Control? The Japanese Way. London: Prentice-Hall.

ISO. (2019). International Standards Organization. Retrieved January 25, 2019, from www.iso.org

Jilcha, K. (2014). Impact of quality on global competitiveness in chemical manufacturing industry. Thesis. Addis Ababa: Addis Ababa Institute of Technology.

Juran, J. M. (2016). Quality Handbook (16 ed.). New York: Juran Institute Inc.

Kanji, G. K. (2012). Measuring business excellence. London: Routledge.

Kaziliunas, A. (2010). Success factors for quality management systems: certification benefits. Intellectual Economics, 2(8), 30-38.

Khoo, H. H., \& Tan, K. C. (2002). Critical success factors for quality management implementation in Russia. Industrial and Commercial Training, 34(7), 263 - 268. 
Kudoma, S. (2015). An analysis of the critical factors in the succesful implementation of total quality management practices by small to medium scale enterprises in Zimbabwe: A case os SMEsat Glenview 8, Harare. Thesis. Harare: University of Zimbabwe.

Kufa, T. (2015). Impact of quality management systems on company performance. A case of Steelmakers Zimbabwe Pvt Ltd. Gweru: Midlands State University.

Kumar, S., Phillips, A., \& Rupp, J. (2009). Using six sigma DMAIC to design a high-quality summer lodge operation. Journal of Retail \& Leisure Property, 8(3), 173-191.

Kurasha, P., \& Gwarinda, T. C. (2014). Strategy and Quality Assurance at the Zimbabwe Open University. Zimbabwe International Journal of Open \& Distance Learning, 1(2).

Kwaka, Y. H., \& Anbari, F. T. (2006). Benefits, obstacles, and future of six sigma approach. Technovation, 26, 708-715.

Lee, J. Larry, P., \& Manoj, K. (2012). Operations Management Process and Supply Chain (10 ed.). England.

Lim, S. A., Antony, J., N., A., \& S., A. (2017). A systematic review of statistical process control implementation in the food manufacturingindustry. Total Quality Management \& Business Excellence, 28(1-2), 176-189.

Mabika, B. (2018). 2018 Improving workers' safety and health in the Zimbabwean mining and quarrying industry. Thesis. Walden University.

Macheka, L., Manditsera, F. A., Ngadze, R. T., Mubaiwa, J., \& Nyanga, L. K. (2013). Barriers, benefits and motivation factors for the implementation of food safety management system in the food sector in Harare Province, Zimbabwe. Food Control, 34, 126-131.

Madanhire, I., \& Mbohwa, C. (2014). Application of Total Quality Management (TQM) and Statistical Process Control (SPC) in improving business competitiveness for Ma. Johannesburg: Intl' Conf. on Chemical, Integrated Waste Management \& Environmental Engineering (ICCIWEE'2014) April 15-16, 2014.

Madanhire, I., Kagande, L., \& Chidziva, C. (2013). Application of Just In Time (JIT) manufacturing concept in aluminium foundry industry in Zimbabwe. International Journal of Science and Research, 2(2).

Madanhirea, I., \& Mbohwa, C. (2016). Application of Statistical Process Control (SPC) in manufacturing industry in a developing country. 13th Global Conference on Sustainable Manufacturing - Decoupling Growth from Resource Use.

Madhekeni, A. (2012). Implementing results-based management systems in Zimbabwe: context and implications for the public sector. International Journal of Humanities and Social Science, $2(8)$.

Maganga, J. (2018). The applicability of business excellence model as an effective strategy to turnaround state-owned-enterprises: a case of national railways of Zimbabwe. Harare: University of Zimbabwe.

Mahmutay, L. R., Jusufi, G., Zylfijaj, K., \& Grubi, A. K. (2015). The role of quality management practices in improving the efficiency and effectiveness of financial services. Mediterranean Journal of Social Sciences, 6.

Mambanda, J., Maibvisira, G., \& Murangwa, S. I. (2017). Effects of Total Quality Management on the performance of the food and beverages industry in Zimbabwe. International Journal of Business and Management Invention, 6(6), 26-36.

Mangwiro, M., Marimo, R. J., \& Ndlovu, A. O. (2015). A study into guests' perceptions of service quality and loyalty in hotel restaurants In Harare. Research journali's Journal of Hospitality Tourism, 2(4).

Maphosa, T. (2015). An investigation of the causes of non-adherence to set quality standards in lodges in Zimbabwe: a case study of operators in Harare. Thesis. Harare: University of Zimbabwe.

Mapolisa, T., \& Mubika, A. K. (2018). Total quality management: The pathway to quality reserach supervision of the postgraduate diploma in education programme at the Zimbabwe Open University. International Journal of Asian Social Science, 3(2), 308-320.

Marambanyika, T., \& Mutekwa, T. (2010). Effectiveness of ISO 14001 environmental management systems in enhancing corporate environmental sustainability at Unilever South East Africa in Harare, Zimbabwe. Journal of Sustainable Development in Africa, 1(1). 
Marufu, J., Chimusoro, E., \& Korodia, M. A. (2014). An assessment of impact of Total Quality Management practices at Parkview Premier Clinical Laboratories. Singaporean Journal of Business Economics, and Management Studies, 2(11).

Masanga, G. G., Munyoro, G., \& Mugwagwa, P. F. (2017). An evaluation of business models in the private healthcare services sector in Zimbabwe: A case study of three healthcare companies in Harare. International Journal of Research in Business Management, 5(5), 117-136.

Masanganise, K., Matope, G., \& Pfukenyi, D. (2013). A survey on auditing, quality assurance systems and legal frameworks in five selected slaughterhouses in Bulawayo, south-western Zimbabwe. Onderstepoort Journal of Veterinary Research, 80(1), 1-8.

Masengu, R., \& Mangwenda, s. (2017). The impact of Hazard Analysis and Critical Control Point (HACCP) certification on sales of liquid milk: a case of the dairy sector, Manicaland, Zimbabwe. International Journal of Economics, Commerce and Management United Kingdom, 5(3).

Masrurul, M. M. (2019). Impact of service quality on customer satisfaction in Bangladesh tourism industry: an empirical study. Advances in Management, 12(1).

Matombo, R. (2014). An investigation into the implementation of Lean Six Sigma as a tool to enhance organizational performance and competitiveness within the Manufacturing Sector: a case of Chloride Zimbabwe (2010 - 2013). Harare: University of Zimbabwe.

Mavaza, T., Halimani, D., Gumbo, L., \& Farai, D. (2017). Total Quality Management (TQM) as a competitive tool in commercial banking in Zimbabwe. International Journal of Research in Finance and Marketing, 7(3), 91-106.

Maware, C., \& Adetunji, O. (2019). Lean manufacturing implementation in Zimbabwean industries: Impact on operational performance. International Journal pof Engineering Management, 11, $1-12$.

Metaxas, N. I., \& Koulouriotis, D. E. (2017). Business excellence measurement: a literature analysis (1990 - 2016). Total Quality Management and Business Excellence.

Mizanbekova, S., Umbetaliev, N., Aitzhanova, A., \& Bogomolov, A. (2017). The Quality Management System improvement for the enhancement of production competitiveness. Revista Espacios, 38(42), 29.

Moheel, B., Alkatheri, S., \& AlSukhayri, A. A. (2019). Critical success factors of Total Quality Management in software development. International Advanced Research Journal in Science, Engineering and Technology, 6(2).

Moustakis, V. S. (2009). A business excellence model for the hotel sector: implementation to highclass Greek hotels. Benchmarking an International Journal, 16(4), 462-483.

Mukwambo, P. (2016). Quality as human development: a case study of teaching and learning in Zimbabwean universities. University of the Free State: Bloemfontein.

Munyimi, T. F. (2019). The role of procurement quality controls in procurement performance in the energy sector in Zimbabwe. Cogent Engineering, 6(1).

Nair, G. K., \& Choudhary, N. (2017). Influence of critical success factors of total quality management on financial and non-financial performance of hospitality industry: an empirical study. International Journal of Productivity and Quality Management - Inderscience, 17(4), 409436.

Ngwenya, B., Sibanda, V., \& Matunzeni, T. (2016). Challenges and benefits of total quality management (TQM) implementation in manufacturing companies: a case study of delta beverages, in Zimbabwe. International Journal of Business Research, 2(6).

Ngwenya, V. C., \& Pretorius, S. G. (2014). Parental Involvement with education in Zimbabwe within a Total Quality Management framework. International Journal of Education Sciences, 7(3), 701-710.

Njobo, L. (2016). The effects of implementing quality management systems (QMS) on the perfomance of parastatals in Zimbabwe: the case of Zimbabwe power company (Munyati Station). Thesis. Gweru: Midlands state University.

Nyambwa, I. S. (2017). An assessment of the challenges faced by manufacturing industries in the implementation of ISO 9001 Quality Management Systems. A case of Harare, Zimbabwe. Bindura: Bindura University of Science Education. 
Nyenya, T., \& Gabi, B. (2016). The impact of the quality assurance unit on quality improvement in Zimbabwe Open University. International Journal of Humanities Social Sciences and Education, 3(2), 88-96.

Nyuke, L. T., \& Gasva, D. (2015). Implementation of quality management principles at Zimbabwe Open University (ZOU)'s selected regional centre: quest for quality. Journal of Business and Management, 18(12), 89-97.

Papanthymou, A., \& Darra, M. (2017). Quality Management in higher education: review and perspectives. Higher Education Studies, 7(3).

Pearlman, D. M., \& Chacko, H. E. (2012). The quest for quality improvement: using six sigma at Starwood hotels and resorts. International Journal of Hospitality \& Tourism Administration.

Psomas, E., Vousaz, F., \& Kafetzopoulos, D. (2014). Quality management benefits through the "soft" and "hard" aspect of TQM in food companies. The TQM Journal, 26(5), 431 - 444.

Rotich, R., Akunja, L., \& Yego, J. (2012). Extent of adoption of Quality Management Systems in the hospitality and catering industry: a study of selected establishments in Nairobi. Food Science and Quality Management, 9.

Sembajwe, R., Shamu, T., Machingura, F., \& Chidawanyika, H. (2018). Implementation of a laboratory information system in Zimbabwe. Online Journal of Public Health Informatics, $10(1)$.

Shirbavikar, K. (2018). Identification of critical success factors for TQM implementation in large and medium scale industries. International Journal of Scientific and Research Publications, 8(2).

Suruto. (2015). Impact of quality management systems on company performance. A case of Steelmakers Zimbabwe Pvt Ltd. Gweru: Midlands State University.

Tapera, J., \& Kuipa, P. K. (2016). Promoting Quality Assurance in Zimbabwean Higher Education Institutions; Concepts, Systems and Processes. Bulawayo .

Tarí, J. J., \& Dick, G. (2016). Trends in quality management research in higher education institutions. Service Theory and Practice, 26(3), 273-296.

Virima, M., Sandada, M., Ndoro, T. R., \& Chuchu, T. (2019). The impact of service quality drivers on customer satisfaction in internet provision services of Zimbabwe. Journal of Business and Retail Management Research, 14(1).

Wang, C. H., Chen, K. Y., \& Chen, S. C. (2012). Total quality management, market orientation and hotel performance: the moderating effects of external environmental factors. International Journal of Hospitality Management, 31(1), 119-129.

Watiki, C. (2014). Service Quality and customer satisfaction in Hotels in Nairobi, Kenya. Nairobi: University of Nairobi.

Wen, D. C., Dai, T., Chen, X., \& Fu, T. (2017). A study on the economic benefits of the Government Quality Award in the Chinese context. Total Quality Management \& Business Excellence, 28(7-8), 712-729.

World Bank. (2020). Zimbabwe Overview. Washington: World Bank.

Yarahmadi, F., \& Magd, H. A. (2016). Factors Affecting the Readiness of Higher Education Institutions 'Environment for the Establishment of TQM in Oman. Paper presented at the Twentieth International Conference on ISO and TQM. Oman: www.hk5sa.com.

Zhanda, E. (2016). Perceptions of Quality Control Management System as a management tool: a case of Kariba South Power Station (2013-2015). Dissertation. Bindura: Bindura University.

Zvavahera, P. (2014). An evaluation of the effectiveness of performance management systems on service delivery in the Zimbabwean civil service. Journal of Management and Marketing Research . 